\title{
(QJPS)
}

Vol. 24, No. 4, pp. $51-55$, Year 2019

\section{Effect of Enterobius vermicularis parasite on IgE antibody levels among children in Al- Diwaniyah City, middle Iraq.}

\author{
Manar Hamid \\ ${ }^{\text {a}}$ College of Science, University of Al-Qadisiyah,Iraq manar.hamid77@gmail.com
}

\begin{abstract}
:
The aim of this study was to detect the concentration of IgE antibody in children infected with Enterobius vermicularis and healthy children as a control group by using Enzyme linked immunosorbent assay (ELISA) technique. The results indicated that there was an increase in the concentration of IgE antibody levels in people with E. vermicularis parasite with an average of (227.08 IU) compared to the control group, and the study of elevation ratios for age, where the results showed that the lowest increase in IgE antibody was recorded in the age group 1-3 years. The highest increase was recorded in the age group between 7 9 years with an average of (306.84 IU). The results of the statistical analysis showed very significant differences indicating a higher level of IgE among people with E. vermicularis parasite compared to the control group at a probability level of 0.05 . The results of the statistical analysis through the use of the F-test showed no significant differences between the high antibody IgE in children with E. vermicularis parasite depending on age groups.
\end{abstract}

KEYWORDS: Immunoglobulin IgE , cellular immunity, Intestinal helminths, immune response .

\section{INTRODUCTION}

The immune system is one of the most complex organisms and shows many signs of co-evolution with parasites, which are well-tuned for its task. Multicellular organisms that do not last long may not survive and outperform their short-lived and multiple parasites. Immune responses among host species vary with many other species such as the environment and the life cycle phase (AlKabee,2014). Similarly, parasites cannot always exercise maximum virulence due to the costs involved. For example, a host may be killed before being fully exploited by the parasite and result in a pattern of host and parasite genotypes, Since only certain parasite genotypes are capable of infecting a particular host genotype and vice versa, only some host genotypes resist a particular set of parasite genotypes (Schmid-Hempel,2009).

The immune response caused by parasitic infection is complex and multiple. In parasitic worms, antiparasitic stimuli stimulate an intense response of Th2 with the production of Interleukin-4 and Interleukin-5 leading to the synthesis of $\operatorname{IgE}$ and activate eosinophil cells (Medeiros et al ., 2006). Acid cell hypertrophy and elevated IgE levels are characteristic of many parasitic worm infections, and when they are not interpreted, hidden worm disease (Yazdanbakhsh,2002). should be sought. Previous studies have shown that IgE antibodies and eosinophil cells play an important role in the immune response to helminthes (Meeusen \& Balic , 2000). Interleukin-4 and Interleukin-5
Th2 responses also increase in IL-9, IL13 and IL21 levels, activating and enlarging CD4 $+\mathrm{TH} 2$ cells, mast cells and basophils, all of which can produce several types of $\mathrm{TH} 2$ cytokines (Robert et al ., 2009).

\section{Immunoglobulin IgE}

$\mathrm{IgE}$ antibody is one of the widely known antibodies due to its involvement in all types of hypersensitivity reactions as well as it can also participate in protecting the body from parasites (Al-Hashemey , 2019). Y-shaped and composed of four chains form the basic units of the construction of the antibody (Monomer).These chains are classified into two similar heavy chains called (Heavy chain) and two similar light chains called (Light chains) .The type of heavy chain is Epsilon on the surface of IgE cells is known to be FceRI, which is high in $\operatorname{IgE}$ and CD23 FceRII, which have a low affinity for IgE, These receptors are found on the surface of mast cells, Eosinophils and Basophils (Kelly \& Grayson , 2016 ; Oettgen , 2016) . IgE antibody is excreted from B and plasma cells (Mukai et al ., 2016 ) . Despite its half-life of less than a day in the plasma, it can last for several weeks or months when it is bound to the cell surface by the FceRI receptor, making it a long gatekeeper (Oettgen , 2016). The main function of IgE is to defend against parasites such as helminths (Fitzsimmons et al ., 2014). Many of these parasitic infections are defended by activating T2assisted T cells, which produce antibodies to IgE. IgE binding to its FceRI receptors on the surface of MC and Basophils is 


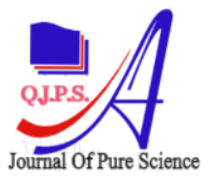

\section{(QJPS)}

Vol. 24, No. 4, pp. 51-55,Year 2019

likely to produce and release substances that play a role in the parasite (Mukai et al ., 2016).

Immunoglobulin IgE, which is found naturally in small amounts in the serum and excreted in less than $0.001 \%$ of all immunoglobulin in the serum. The neonatal level of the total $\operatorname{IgE}$ is less than 1IU / MI. IgE levels show a slow increase during childhood to adult levels in the second decade and are generally responsible for allergic reactions, however, it is necessary to mean that about $30 \%$ of patients with allergic manifestations can have a normal level of the total IgE, in contrast, high levels of IgE can be detected in anyone without any sensitivity. These high antibodies cause a smooth muscle contraction and eventually lead to allergic conditions such as skin reactions, allergic reactions, chills, dermatitis, rhinitis, hay fever, asthma and allergic shock (Al-kape,2014). Worm allergens are potent inducers of IgE production and stimulate strong IgE responses in humans but may contribute to host immunity against parasitic worms or life-cycle phases. It has been suggested that high levels of polyclonal IgE are a defense mechanism against worms against IgE antiparasitic effects (Villarreal et al ., 1999). The immune response to IgE began with Blymphocytes produced by TH-2 lymphocytes (IL-4 + IL-5). IgE production is a response to initial exposure to an antigen or an allergen (Rosario et al ., 2007).

The relationship of pinworms in high IgE antibody level

As a result of the impact of intestinal parasites on some immune indicators, including $\operatorname{IgE}$ antibody has been conducted several studies on this subject, the most important of which came in a study in Nigerian Okada where 334 children under the age of 15 years were examined, the results of the study recorded that the total infection rate of parasites $50 \%$ of children aged 5-11 years had the highest rate of intestinal parasites and in both sexes, and in contrast, children under 5 years of age had the lowest rate of intestinal parasites. IgE in sucking Blood of children with intestinal parasites compared with uninfected children (Ehiaghe et al ., 2013).

In Northwest Ethiopia, (Amare et al ., 2013) conducted a study to determine the nutritional status, intestinal parasite infestation, and allergy among primary school children. With no subjects with an average concentration of (344 IU / $\mathrm{ml}$ ), it was concluded that there was no association with $\operatorname{IgE}$ concentration with a parasitic infection or an allergy history.

In Iraq, specifically Karbala Governorate, the results of the study showed that the concentration of antibody $\operatorname{IgE}$ and interleukin-5 and histamine in the serum of children with intestinal parasites reached an average $(56.63 \mathrm{IU} / \mathrm{ml}, 22.08$ $\mathrm{pg} / \mathrm{ml}$ and $76.27 \mathrm{ng} / \mathrm{ml}$ respectively) A comparison with the group of uninfected children $(42.76 \mathrm{IU} / \mathrm{ml}, 15.43 \mathrm{pg} / \mathrm{ml}$ and $65.35 \mathrm{ng} / \mathrm{ml}$ respectively), the statistical analysis showed that there were significant differences in the concentrations of these criteria in children with and without intestinal parasites (Al-Hashemey, 2019).

As for Al-Diwaniya Governorate, an immunological study was conducted for people infected with pinworm parasites, where the results of the study showed a noticeable increase in the levels of IgE among people with parasite with a mean ( $377.4481 \mathrm{IU} / \mathrm{ml}$ ) and by $36 \%$ compared to the control group and with an average (29.28175 units) International/ml) (AlKabee, 2014).

\section{2- Materials and methods of work Collect the blood samples.}

About (cc2) of venous blood was collected for the 90pinworm patients after confirming the diagnosis of infection by microscopic examination of stool samples for children aged 112 years, and was allowed to coagulate in $37^{\circ} \mathrm{C}$ using centrifugation and then stored in $-20^{\circ} \mathrm{C}$ until Use for the purpose of immunological examination.

The ELISA kit used in this research was prepared by the Dutch company CALBIOTECH with following the publication steps provided by this company.

Detection of IgE antibody levels in the serum of children with E.vermicularis infection

\section{Test principle:}

Total IgE is a single, immune, step-by-step basis of the sandwich method. Based on the principle of Streptavidin-biotin. This is done by fixing the antigens or antibodies in the plate's plastic holes where the serum and standard samples are placed in the Streptavidin-coated Microwell drill. The internal IgE of the patient's serum is associated with the antibody-antigen of the antibiotic IgE. Simultaneously the antibiotic is frozen into the pits by a high Streptavidin-Biotin reaction, the non-bound protein and excess biotin antibodies are washed by the Wash buffer. Then add an enzyme linked to the anti-molecule Enzyme Conjugate and incubate for half an hour and then wash again, then add the substrate to the base material and incubate the plate, which leads to the development of blue color and then add a stop solution to stop the reaction where the color becomes yellow in the holes, the concentration of $\operatorname{IgE}$ is directly proportional to the color intensity in the test sample. Absorption is measured using a $450 \mathrm{~nm}$ wavelength spectrometer (AlKabee , 2014).

\section{3- Results and discussion}

The study included measuring the levels of serum IgE by the IgE ELISA kit group, and 90 blood serum samples were tested, 70 of which were infected with the E.vermicularis parasite (positive in fecal tests) belonging to 35 males, 35 of whom are females, and 20 serum were healthy children as a Control group includes 10 males and 10 females. These results show that among those with the Evermicularis 39 parasite, that is, $55.71 \%$ had a positive examination of $\operatorname{IgE}$ with a mean (227.09 IU), while $31,44.28 \%$ of patients with a negative examination (IgE (37.87 IU) compared with the results of the control group negativity for IgE examination with mean (48.66 IU).

The results of the statistical analysis showed the presence of very clear significant differences indicating the high level of IgE among those with the Evermicularis parasite compared with the control group at the probability level 0.05 , as shown in Table (1). These results are higher and are consistent with the results of (Al-Kabee , 2014). That observed a 36\% increase in IgE levels in children with pinworms in Al-Diwaniyah governorate. It also agreed with (Durmaz et a1.,1996). Who 52 


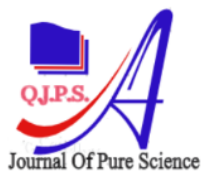

\section{Al-Qadisiyah Journal Of Pure Science (QJPS)}

Vol. 24, No. 4, pp. $51-55$, Year 2019

observed that levels of $\mathrm{IgE}$ decreased significantly after anti-parasite treatment. The result is also consistent with the result of (Al-Hashemey, 2019) That showed high levels of $\mathrm{IgE}$ in people with an average score of $56.63 \mathrm{IU}$ compared to the control group with an average score of $42.76 \mathrm{IU}$. The ability of helminthes to manipulate the immune system of their host to ensure their survival and the host often has an immune response to other pathogens (Fibey et al ., 2019). The main function of $\operatorname{IgE}$ is to immune parasites such as helminths, and important levels of $\operatorname{IgE}$ have been studied in people with helminths or parasites infection. Although higher IgE was higher in worm infection than that of parasites, Bengul et al . (1996) showed that children with the E.vermicularis parasite had higher IgE levels than found in G.lamblia and Perlmann et al . (1994) who demonstrated importance during immune defense against some primary parasites such as Plasmodium falciparum.

Table (1): Immunological Variables represented by Examination of IgE Levels in People with E. vermicularis Parasite Compared to the Healthy Group (Control Group).

\begin{tabular}{|c|c|}
\hline The group & Rate \pm Standard deviation \\
\hline Healthy & $48.67 \pm 38.24$ \\
\hline Infected & $227.08 \pm 156.08$ \\
\hline T-test & $\mathbf{8 . 6 9 0}$ \\
\hline P value & $0^{*}$ \\
\hline
\end{tabular}

* There are significant differences at the probability level 0.05 .

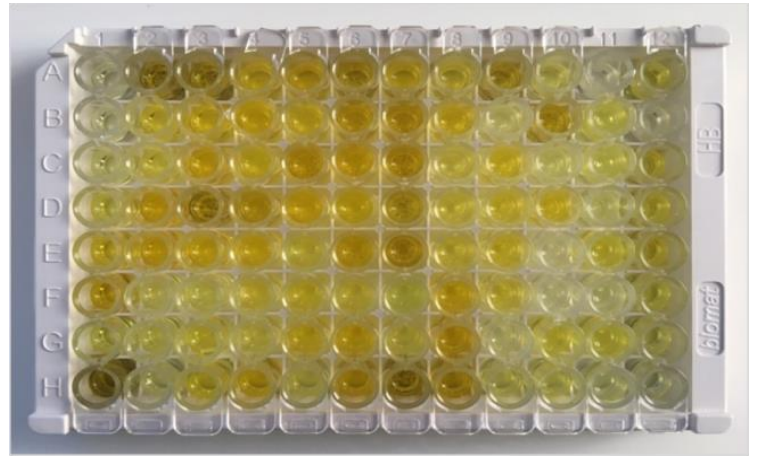

Fig. (1): IgE screening results for E. vermicularis and healthy individuals using ELISA

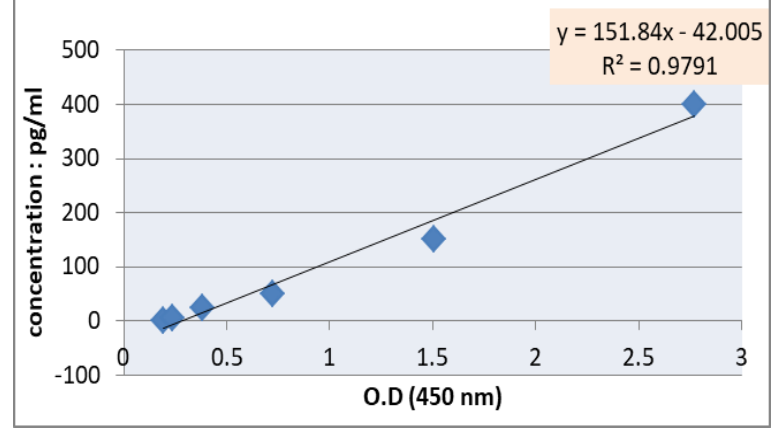

Fig (2): Curve for IgE ELISA screening.

Table (2) shows the concentrations of IgE antibody among children infected with pinworm parasites in Al-Qadisiyah governorate depending on the age groups. The highest serum mean in the age group 7-9 years was $306.68 \mathrm{IU}$. The results of the statistical analysis using the F-test showed no significant differences between the high antibody $\operatorname{IgE}$ in children with pinworm parasites depending on age groups. IgE antibody levels were divided based on age groups and not on the sex of children depending on (Rezaeipoor \& Zadeh, 1993).

Table (2): $\operatorname{IgE}$ antibody concentrations for E. vermicularis parasites for age groups.

\begin{tabular}{|c|c|c|}
\hline Age groups & Numbers & Mean \pm SE \\
\hline $1-3$ & 14 & $196.85 \pm 42.71$ \\
\hline $4-6$ & 27 & $207.2 \pm 27.83$ \\
\hline $7-9$ & 11 & $306.84 \pm 50.92$ \\
\hline $10-12$ & 18 & $231.68 \pm 37.36$ \\
\hline Total & 70 & $227.08 \pm 18.66$ \\
\hline F test & \multicolumn{2}{|c|}{1.299} \\
\hline P-value & \multicolumn{2}{|c|}{$0.282(\mathrm{NS})$} \\
\hline
\end{tabular}

Parasitic infections not only stimulate the production of $\operatorname{IgE}$ antibodies to the parasite but also stimulate the nonspecific polyclonal IgE synthesis (Nagaraji et al .,2004). The significant increase in $\mathrm{IgE}$ antibody concentration in children with intestinal parasites compared to non-infected children may be due to the immune response and host defense mechanism against the parasite and its toxins, which may vary depending on the type of parasite that causes the infection (Mukai et al ., 2016). Many parasitic infections are defended by activating T2assisted T-cells, leading to the production of IgE antibodies and activating the role of eosinophil cells (Amâncio et al ., 2012). Since the increase in IgE levels with its high receptor FceRI on the surface of cells such as MC cells and Basophils and the 


\section{(QJPS)}

Vol. 24, No. 4, pp. $51-55$, Year 2019

activation that follows to these influential cells to produce and release biological mediators such as histamine and some other active amines that have an important role in the expulsion of the parasite, there is another mechanism in the expulsion the parasite is an antibody-dependent cellmediated cytotoxicity via IgE or IgG receptors (Mukai et al ., 2016).

As for the potential roles of $\operatorname{IgE}$ in host defense against toxins, tissue injury appears to be the main cause of immune responses to T2 cells (Kelly \& Grayson, 2016 ; Mukai et al ., 2016). In mammals including humans, Th2 responses may lead to a general function in host defense, including as a protective mechanism against toxins and other harmful substances as well as identification of worm-acquired immunity and possibly other pathogens (Al-Hashemey , 2019 ; Al-Ibrahimi , 2019). Most toxins are a complex mixture of biologically active amines, peptides, and enzymes and often have toxic or neurotoxic activity. However, many toxins also contain compounds that cause tissue damage, so toxin-induced tissue damage can generate major risk signals. It is sensed by the immune system that initiates type 2 immunity and directs the development of IgE antibodies (Mukai et al ., 2016).

\section{4- Conclusion}

The immune response caused by parasitic infection is complex and multiple. In parasitic worms, especially E.vermicularis, antiparasitic stimuli stimulate an intense response of Th2 with the production of Interleukin-4 and Interleukin-5 leading to the synthesis of $\operatorname{IgE}$ immunoglobulin.

The results of this study conclude that the antibody level of $\mathrm{IgE}$ is higher in people with E.vermicularis parasite, and its height is related to age and not sex.

\section{5- References}

AL-Hashemy, I.H.M, AL-Tameeme, T.A , Al-Morshidy, K.A. (2019). Study of variations in allergy and blood parameters in patients with intestinal parasites. College of Science at the University of Karbala Master in Biology.

Al-Ibrahimi, M.H.M and Al-Waaly, A.B.M. (2019). The prevalence of pinworm, incontinence and appendicitis in children in Diwaniyah Governorate, Iraq, Journal of Annals of Tropical Medicine and Public Health, 23(1).

Al-kabee ,R.M.R; Dawood; K. A, Al-Essami; A. H: (2014). Epidemiological Immunological and molecular study of Enterobius vermicularis in $\mathrm{Al}$ Diawnia Governorate, College of Medicine/ Al Qadisiya University, Master of Science in Medical Microbiology.

Amâncio, F. A. M.; Pascotto, V. M.; Souza, L. R.; Calvi, S. A., \& Pereira, P. C. M. (2012). Intestinal parasitic infections in HIV/AIDS patients: epidemiological, nutritional and immunological aspects. Journal of Venomous Animals and Toxins including Tropical Diseases, 18(2): 225-235.

Amare, B.; Ali, J.; Moges, B.; Yismaw, G.; Belyhun, Y. ; Gebretsadik, S., ... \& Tegabu, D. (2013). Nutritional status, intestinal parasite infection and allergy among school children in Northwest Ethiopia. BMC pediatrics, 13(1): 7 .

Bengül, D.; Cengiz Y.; Mehmet, K.; Mehmet, R.; Riza, D. and Sami, Y. (1996). Concentrations of Total Serum IgE in Parasitized Children and the Effects of the Antiparasitic Therapy on IgE Levels. Turgut Özal Tip Merkezi Dergisi., 3: 332-335.

Durmaz, B.; Yakinci, C.; Köroglu, M.; Rafiq, M.; Durmaz, R. and Yologlu, S. (1996). Concentrations of Total Serum IgE in Parasitized Children and the Effects of the Antiparasitic Therapy on IgE Levels. Turgut özal Tip Merkezi Dergisi, 3(4): 332-335.

Ehiaghe, A.F.; Tatfeng, Y.M.; Ehiaghe, J.I.\& Osaretin, U. (2013). Hemoglobin concentration of intestinal parasites infested children in Okada, Edo State, Nigeria. Open Journal of Epidemiology, (3 ):149-152. eosinophil and $\operatorname{IgE}$ levels in allergic rhinitis. Bezmialem University School of Medicine, İstanbul, Turkey. The European Research Journal 2018;4(4):399-404.

Filbey,K.J; Camberis,M; Chandler,J; Turner,R; Kettle,A.J ., Eichenberger,R.M; Giacomin,P and Gros1,G.L (2019). Intestinal helminth infection promotes IL-5and $\mathrm{CD} 4+\mathrm{T}$ celldependent immunity in the lung against migrating parasites. Department of Pathology \& Biological Science, University of Otago, Christchurch, New Zealand and 3Australian Institute of Tropical Health and Medicine, James Cook University, Cairns, Australia Mucosal Immunology $12: 352-362$.

Fitzsimmons, C. M.; Falcone, F. H. \& Dunne, D. W. (2014). Helminthes allergens, parasite-specific $\operatorname{IgE}$, and its protective role in human immunity. Frontiers in immunology, 5: 61 .

Kelly, B. T. \& Grayson, M. H. (2016). Immunoglobulin E, what is it good for?. Annals of Allergy, Asthma \& Immunology, 116(3):183-187.

Medeiros, D.; Silva, A.R.; Rizzo, JA.; Motta, M.E.; de Oliveira, F.H.B. and Sarinho, E.S.C. (2006). Serum total IgE in respiratory allergy: a study of patients at high risk of helminth infection. J pediatric. 82(4):2559. 


\section{Al-Qadisiyah Journal Of Pure Science (QJPS)}

Vol. 24, No. 4, pp. 51-55, Year 2019

Meeusen, E.N and Balic, A. (2000). Do eosinophils have a role in the killing of helminth parasites? Parasitol Today .16: 95-101.

Mukai, K.; Tsai, M.; Starkl, P.; Marichal, T. \& Galli, S. J. (2016). IgE and mast cells in host defense against parasites and venoms. In Seminars in immunopathology. Springer Berlin Heidelberg,38(5): 581-603.

Nagaraji, S.; Raghavan, R.; Macaden, R. and Kurpad, A.V. (2004). Intestinal parasitic infection and total serum IgE in a symtoatic adult males in an urban slum and efficacy of antiparasiic therapy. Indian $\mathbf{J}$ Med Microb., 22(1): 54-6.

Oettgen, H. C. (2016). Fifty years later: emerging functions of $\operatorname{IgE}$ antibodies in host defense, immune regulation, and allergic diseases. Journal of Allergy and Clinical Immunology, 137(6): 16311645 .

Perlmann, H; Helmby, $\mathrm{H}$ and Hagstedt, M.(1994). IgE elevation and $\operatorname{IgE}$ antimalarial antibodies in Plasmodium falciparum malaria association of high IgE levels with cerebral malaria. Clin. Exp. Immunol (England).97:284-92.

Rezaeipoor, R. \& Mohammad Zadeh, H. R. (1993). ASSESSMENT OF NORMAL IgE LEVEL IN 014 YEAR OLD HEALTHY CHILDREN IN TEHRAN. Medical Journal of The Islamic Republic of Iran (MJIRI), 6(4): 269-272.

Roberts , L and Janovy, J. (2009). Foundation of Parasitology.8th edition. Mc Graw Hill., USA.;470.

Rosário, N.A.; Carneiro, M.F.; Ferreira, E. and Baranski, M.C. (2007). Níveis de IgE total no soro, eosinófilos em crianças com enteroparasitoses: efeito do tratamento antihelmíntico. J Pediatri., 52(4): 209-15.

Schmid-Hempel, P. (2009). Immune defense, parasite evasion strategies and their relevance for 'macroscopic phenomena' such as virulence. Philosophical Transactions Biological Sciences, 364: 85-98.

Villarreal, O.; Villarreal, J.J. and Domingo, J.A.(1999).Progressive eosinophilia and elevated $\mathrm{IgE}$ in enterobiasis. Allergy European Journal of allergy and clinical immunology.54( 6):P 646648.

Yazdanbakhsh, M:(2002). Allergy, parasites, and the hygiene hypothesis. Science 296:490. 